\title{
Determination of Monthly Unit Cost of Energy for Standalone Photovoltaic System in Owerri, Imo State
}

\author{
Umoren Mfonobong Anthony, Mfonobong Charles Uko, Ogungbemi Emmanuel Oluropo
}

Department of Electrical/Electronic and Computer Engineering, University of Uyo, Akwa Ibom, Nigeria

\section{Email address:}

umoren_m.anthony@yahoo.com(U. M. Anthony)

\section{To cite this article:}

Umoren Mfonobong Anthony, Mfonobong Charles Uko, Ogungbemi Emmanuel Oluropo. Determination of Monthly Unit Cost of Energy for Standalone Photovoltaic System in Owerri, Imo State. American Journal of Mechanical and Industrial Engineering.

Vol. 2, No. 2, 2017, pp. 104-110. doi: 10.11648/j.ajmie.20170202.17

Received: October 31, 2016; Accepted: January 4, 2017; Published: January 29, 2017

\begin{abstract}
In this paper, simulation approach is used for determination of the monthly unit cost of energy generated from standalone PV (SAPV) power system in Imo State. The meteorological data used in the study are compiled from National Aeronautics and Space Administration (NASA) worldwide meteorological database. The meteorological data include 22-year monthly and annual averaged insolation incident on a horizontal surface $(\mathrm{kwh} / \mathrm{m} 2 /$ day) and 22-year monthly averaged air temperature. A hypothetical electric load demand data of $5000 \mathrm{kWh}$ per day is used for the simulation. The PVsyst industrial PV system planning software solution was selected to model and simulate the entire PV system. PVSyst uses life cycle cost analysis approach to determine the investment cost and unit cost of energy generated from SAPV system. According to the results, the average total energy supplied to the user (load) in a year is $1751 \mathrm{kWh}$. The economic analysis result shows that the total annual cost of energy is 246760 Naira per year at a unit cost of 141 Naira per kWh. Also, the highest unit cost of energy of 168.6 Naira/ $\mathrm{kWh}$ occurred in August whereas the lowest unit cost of energy of $132.7 \mathrm{Naira} / \mathrm{kWh}$ occurred in October. The idea presented in this paper is useful for smart grid, dynamic energy pricing and energy cost management system.
\end{abstract}

Keywords: Photovoltaic System, PVSyst, De-Rate Factor, Unit Cost of Energy, Electric Load Demand

\section{Introduction}

Electricity is the lifeblood of the any nation's economy. It powers our homes, offices, and industries; provides communications, entertainment, and medical services; powers computers, technology, and the Internet; and runs various forms of transportation. Not only is electricity the most flexible and most controllable form of energy, its versatility is unparalleled. Without electricity the world would be a very different place. The public relies on electricity to be readily available and to perform basic functions. Given the continual rise in population and discovery of more power dependent devices and systems, electricity use has continued to be on the increase every year and at the same time, energy prices are rising and energy availability is diminishing [1, 2, 3]. With this continual growth in electricity demand as well as an increasing price, new methods of producing electricity are constantly being developed. The turn to alternative energies to produce electricity dates all the way back to the 18th century but has gained momentum recently. Alternative energy like renewable energy comes from sources that replenish themselves, such as the sun, rivers, wind, and ocean waves and tides $[4,5,6]$.

Among these alternative energy sources, solar energy is one of the most important renewable energy sources that has been gaining increased attention in recent years [7, 8, 9]. Solar panels absorb the sunlight to create electricity. The governments across the globe are putting up policies to assist consumers and investor to adopt solar energy power systems in hope of supporting the "green" or sustainability movement. Solar energy is clean and free of emissions, which is great for the environment, as it does not produce pollutants or by-products harmful to nature $[10,11]$.

In view of the need to encourage rapid and wide-scale adoption of solar power, the cost implication of solar power systems is required. There are cost estimation tools that are used to estimate the cost of PV power system based on the total annual energy produced and the cost of acquiring, maintaining and replacing broken down components of the PV power system. In this project the monthly unit cost of energy from standalone PV system is computed. The monthly 
unit cost of energy useful for dynamic energy pricing and cost management system. Relevant mathematical expressions are presented for calculating the monthly unit cost of energy for photovoltaic power system.

\section{Design Methodology}

In this paper, simulation approach is used for the determination of the monthly unit cost of energy generated from standalone PV (SAPV) power system in Imo State. The meteorological data used in the study are compiled from National Aeronautics and Space Administration (NASA) worldwide meteorological database. The meteorological data include 22-year monthly and annual averaged insolation incident on a horizontal surface $(\mathrm{kwh} / \mathrm{m} 2 /$ day) and 22-year monthly averaged air temperature. A hypothetical electric load demand data is used for the simulation. The PVsyst industrial PV system planning software solution was selected to model and simulate the entire PV system. PVSyst uses life cycle cost analysis approach to determine the investment cost and unit cost of energy generated from SAPV system.

\subsection{Determination of the PV Electric Energy Output}

For any given daily load demand $\left(E_{L}\right)$ in $K w h /$ day with de-rating factors and the $\mathrm{PV}$ size in terms of area $\left(A_{p v}\right)$ required to meet the daily load demand is given as $[12,13,14$, $15,16]$;

$$
A_{p v}=\frac{E_{L}}{\left(G_{d} * \eta_{p v} * f_{d c / a c} * \mathrm{f}_{\mathrm{temp}}\right)}
$$

Conversely, for any given PV size in terms of area $\left(A_{p v}\right)$, the daily load demand $\left(E_{L}\right)$ the PV can satisfy is given as [12, 13, 14, 15, 16];

$$
E_{L}=A_{p v}\left(G_{d} * \mathrm{\eta}_{p v} * f_{d c / a c} * \mathrm{f}_{\mathrm{temp}}\right)
$$

Where

$A_{p v}$ is the PV area in $m^{2}$

$E_{L}$ is the daily load demand in Kwh/day

$G_{d}$ is the solar global insolation based on the global air-mass 1.5 spectrum of $1000 \mathrm{w} / \mathrm{m}^{2}$

$\eta_{p v}$ is the module efficiency

$f_{d c / a c}-\mathrm{DC}$ to $\mathrm{AC}$ de-rating factor [\%];

$f_{\text {temp }}=$ temperature de-rating factor, dimensionless

The DC to AC de-rate factor, $f_{d c / a c}$ is the overall DC to AC de-rate factor which is calculated by multiplying the component de-rate factors $[12,13,14,15,16]$. In most cases, the overall default value of 0.77 will provide a reasonable estimate for modelling the energy production.

The temperature de-rating factor is given as $[12,13,14,15$, 16];

$$
\mathrm{f}_{\mathrm{temp}}=1-\left(\gamma_{\mathrm{pv}} *\left(\mathrm{~T}_{\mathrm{c}}-\mathrm{T}_{\mathrm{STC}}\right)\right)
$$

where

$f_{\text {temp }}=$ temperature de-rating factor, dimensionless

$\gamma_{p v}=$ temperature coefficient of power, that is, the absolute value of power temperature co-efficient per degree Celsius
$\mathrm{T}_{\mathrm{c}}=$ average daily cell temperature,

$\mathrm{T}_{\mathrm{STC}}=$ in degrees Celsius cell temperature at Standard Test Conditions, in degrees Celsius.

For example, assume the average ambient temperature is $25^{\circ} \mathrm{C}\left(T_{a}\right)$ and the module is polycrystalline. The average daily effective cell temperature is $[12,13,14,15,16]$;

$$
T c=T a+25=25+25=50
$$

$$
T c=25+25=50 \text { when } \mathrm{Ta}=25^{\circ} \mathrm{C}
$$

In the above formula the absolute value of the temperature coefficient $\left[\gamma_{p v}=0.5 \% /{ }^{\circ} \mathrm{C}\right]$ and cell temperature at Standard Test Conditions is $25^{\circ} \mathrm{C}$. Therefore the effective derating factor due to temperature is: $1-(50-25) \mathrm{x}$ $0.5 \%=1-12.5 \%=1-0.125=0.875$.

\subsection{Life Cycle Cost Analysis}

The process of identifying and documenting all the costs involved over the life of an asset is known as Life Cycle Costing (LCC). Life-cycle cost analysis (LCCA) is a method for assessing the total cost of system/facility or equipment ownership [17, 18, 19]. It takes into account all costs of acquiring, operating, maintaining and disposing of a system. Analyzing costs over the life of a facility or equipment is key to understanding return on investment and to making investment decisions based on true costs versus initial costs $[17,18,19]$.

The life cycle cost (LCC) method is used to estimate the cost of the proposed PV system. The LCC of an item consists of the total costs of owning and operating an item over its lifetime, expressed in today's money. The costs of the PV system include acquisition costs, operating costs, maintenance costs, and replacement costs. Table 1 gives the list of the components of the data used in the LCC analysis.

Table 1. List of Components Of The Data Used In The LCC Analysis.

\begin{tabular}{lll}
\hline Item & Variable Name & Cost \\
\hline PV module & $C_{\mathrm{cv} / \mathrm{wp}}$ & $\mathrm{N} / \mathrm{WP}$ \\
Battery & $C_{\mathrm{b} / \mathrm{ah}}$ & $\mathrm{Ah}$ \\
MPPT charger & $C_{\mathrm{cg} / \mathrm{a}}$ & $\mathrm{A}$ \\
Inverter & $C_{\text {inv/w }}$ & $\mathrm{N} / \mathrm{W}$ \\
Installation & $C_{\text {inst }}$ & $10 \%$ of PV cost \\
$\mathrm{O \& M} / \mathrm{yr}$ & $C_{\mathrm{o \& m}}$ & $2 \%$ of PV cost \\
\hline
\end{tabular}

The LCC of the PV system includes the sum of all the Present Worths (PWs) of the costs of the PV modules, batteries, MPPT charger controllers, inverter, the cost of the installation and the operation and maintenance (O\&M ) cost of the system $[20,21,22,23]$. In this study, the lifetime, $\mathrm{N}$ of all the PV system items is considered to be 25 years, except that of the battery which is considered to be 5 years. Therefore, an extra 4 groups of batteries should be purchased, after 5 years, 10 years, 15 years and 20years. The inflation rate is $\mathrm{i}$ and a discount or interest rate is $\mathrm{d} \%$. The PWs of all the items are calculated as follows [20, 21, 22, 23]:

$$
\begin{gathered}
\mathrm{PV} \text { array cost, } C_{\mathrm{PV}}=C_{\mathrm{cv} / \mathrm{wp}} * P V_{\mathrm{wp}} \\
\text { Initial cost of batteries, } C_{\mathrm{b}}=C_{\mathrm{b} / \mathrm{ah}} * b_{\mathrm{ah}}
\end{gathered}
$$


The PW of the first extra group of batteries (purchased after $\mathrm{N}=5$ years) $\mathrm{Cb} 1 \mathrm{PW}$ is calculated from:

$$
\mathrm{C}_{\mathrm{b} 1 \mathrm{PW}}=\mathrm{C}_{\mathrm{b}} *\left(\frac{(1 * \mathrm{i})}{(1 * \mathrm{~d})}\right)^{\mathrm{N}} \text { where } \mathrm{N}=5
$$

The Present Worth (PW) of the second extra group of batteries (purchased after $\mathrm{N}=10$ years) $\mathrm{C}_{\mathrm{b} 2 \mathrm{PW}}$, the third extra group (purchased after $\mathrm{N}=15$ years) $\mathrm{C}_{\mathrm{b} 3 \mathrm{PW}}$ and the fourth extra group (purchased after $\mathrm{N}=20$ are respectively calculated from:

$$
\begin{aligned}
& C_{\mathrm{b} 2 \mathrm{PW}}=C_{\mathrm{b}} *\left(\frac{(1 * i)}{(1 * d)}\right)^{N} \text { where } \mathrm{N}=10 \\
& C_{\mathrm{b} 3 \mathrm{PW}}=C_{\mathrm{b}} *\left(\frac{(1 * i)}{(1 * d)}\right)^{N} \text { where } \mathrm{N}=15 \\
& C_{\mathrm{b} 4 \mathrm{PW}}=C_{\mathrm{b}} *\left(\frac{(1 * i)}{(1 * d)}\right)^{N} \text { where } \mathrm{N}=20
\end{aligned}
$$

Controller cost, $\mathrm{C}_{\text {controller }}=\mathrm{C}_{\mathrm{cg} / \mathrm{a}} *$ Controller $_{\mathrm{A}}$ Inverter cost $\mathrm{C}_{\mathrm{inv}}=\mathrm{C}_{\mathrm{inv} / \mathrm{w}} * \operatorname{Inv}_{\mathrm{w}}$

Installation cost $\mathrm{C}_{\text {inst }}=0.1 * C_{\mathrm{PV}}$

Maintenance cost per year $C_{\left(\frac{\mathrm{M}}{y r}\right)}=0.2 * C_{\mathrm{PV}}$

The PW of the maintenance cost CMPW can be calculated using the maintenance cost per year $\left(C_{\left(\frac{\mathrm{M}}{y r}\right)}\right)$ and the lifetime of the system $(\mathrm{N}=25$ years $)$, from:

$$
C_{\mathrm{MPW}}=C_{\left(\frac{\mathrm{M}}{y r}\right)} *\left(\frac{(1 * i)}{(1 * d)}\right) *\left[\frac{\left(1-\left(\frac{(1 * i)}{(1 * d)}\right)^{N}\right)}{\left(1-\left(\frac{(1 * i)}{(1 * d)}\right)\right)}\right]^{N}
$$

The life cycle of the PV system can be calculated as follows:

$$
\begin{gathered}
\mathrm{LCC}=C_{\mathrm{PV}}+C_{\mathrm{b}}+C_{\mathrm{b} 1 \mathrm{PW}}+C_{\mathrm{b} 2 \mathrm{PW}}+C_{\mathrm{b} 3 \mathrm{PW}}+C_{\mathrm{b} 4 \mathrm{PW}}+ \\
C_{\text {controller }}+C_{\mathrm{inv}}+C_{\mathrm{inst}}+C_{\mathrm{MPW}}
\end{gathered}
$$

The annualized LCC (ALCC) of the PV system in terms of the present day Naira can be calculated using the following equation:

$$
A L C C=\operatorname{LCC} *\left[\frac{\left(1-\left(\frac{(1 * i)}{(1 * d)}\right)^{N}\right)}{\left(1-\left(\frac{(1 * i)}{(1 * d)}\right)\right)}\right]^{N}
$$

Finally, the unit electrical cost (cost of $1 \mathrm{kWh})$ can be calculated as follows:

$$
\text { Unit electrical cost }=\frac{\mathrm{ALCC}}{365 * \mathrm{E}_{\mathrm{L}}}
$$

\subsection{Determination of the Monthly Unit Cost of Energy}

The standalone PV (SAPV) system is simulated using PVSyst 5.21. At the end of the simulation the PVSyst generates results that include the unit cost of energy from the SAPV. The unit cost of energy from the PVSyst is based on the yearly total energy supplied to the load. As such, the result from PVSyst is the annual average unit cost of energy. The monthly energy supplied to the load can then be used to determine the monthly unit cost of energy. Let the total annual cost of energy be: $C_{\text {annual }}$; let the annual unit cost of energy be: $U_{\text {annual }}$; let the total energy supplied to the user in the a year be: $E_{\text {annual }}$; let the unit cost of energy for the month $\mathrm{i}$ be: $U_{i}$ and let the total energy supplied to the user in the month $\mathrm{i}$ be: $E_{i}$. Now

$$
C_{\text {annual }}=E_{\text {annual }}\left(U_{\text {annual }}\right)
$$

The total annual energy that will be supplied to the user if the energy to the user is maintained at the month i's value if denoted as $E_{m(i)}$ where;

$$
E_{m(i)}=12\left(E_{i}\right)
$$

Then,

$$
C_{\text {annual }}=E_{m(i)}\left(U_{i}\right)=12\left(E_{i}\right)\left(U_{i}\right)
$$

Therefore,

$$
\begin{gathered}
12\left(E_{i}\right)\left(U_{i}\right)=E_{\text {annual }}\left(U_{\text {annual }}\right) \\
U_{i}=\frac{E_{\text {annual }}\left(U_{\text {annual }}\right)}{12\left(E_{i}\right)}
\end{gathered}
$$

\section{The Simulation and Results}

The load demand is shown in Table 2 is used for the analysis

Table 2. The Hypothetical Load Used For The Analysis.

\begin{tabular}{llll}
\hline Total Watts/Day & Hours/Day & Wh/day & $\mathbf{k W h} /$ day \\
\hline 2500 & 5 & 12500 & 12.500 \\
\hline
\end{tabular}

The requisite input data are entered into the PVSyst. The data include among others, the meteorological data, the load demand, the battery sizing data, PV module sizing data, inverter, along with the input data for the economic analysis. Figure 1 shows a screenshot of the input for the economics analysis.

Figure 2 shows the hypothetical daily load demand, as presented in the simulation results. The hypothetical load has daily power demand of 2500 watts which runs for an average of 5 hours per day resulting in daily energy demand of $12500 \mathrm{Wh} /$ day.

According to Figure 3, the PV system supplies about $96 \%$ of the load demand. The remaining $4 \%$ of the load demand cannot be met. The total energy supplied to the user (load) in a year is denoted in Figure 3 as E_User where the annual E_User is $1751 \mathrm{kWh}$. The economic analysis result, figure 4 shows the total annual cost of energy is 246760 Naira per year at a unit cost of 141 Naira per $\mathrm{kWh}$.

From figure 4 , it can be seen that $C_{\text {annual }}=246760$ Naira per year and $U_{\text {annual }}=141$ Naira per $\mathrm{kWh}$. From the result in Table 3, the highest unit cost of energy of 168.6 Naira/ kWh occurred in August whereas the lowest unit cost of energy of $132.7 \mathrm{Naira} / \mathrm{kWh}$ occurred in October. 


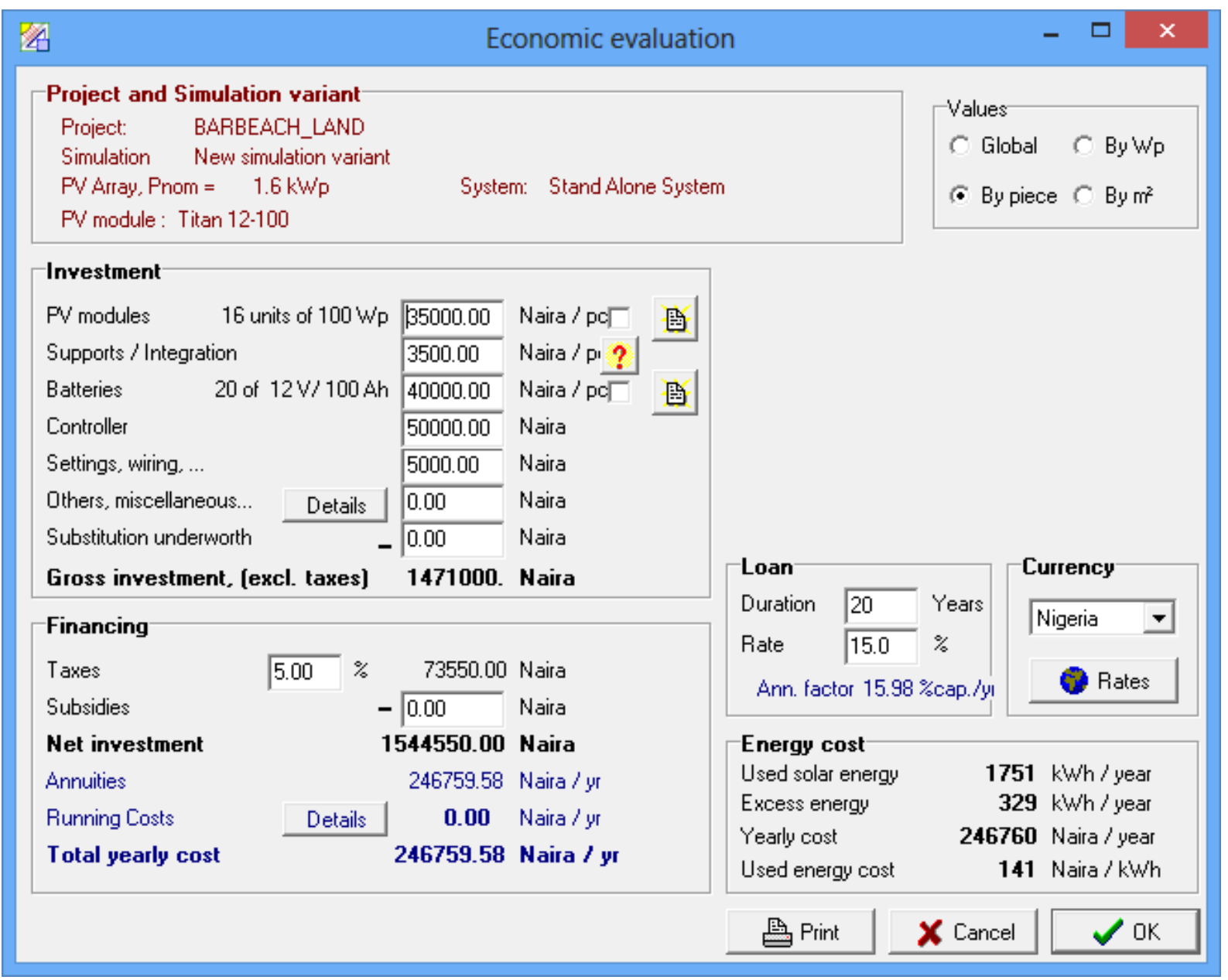

Figure 1. Economic Analysis Dialogue Box.

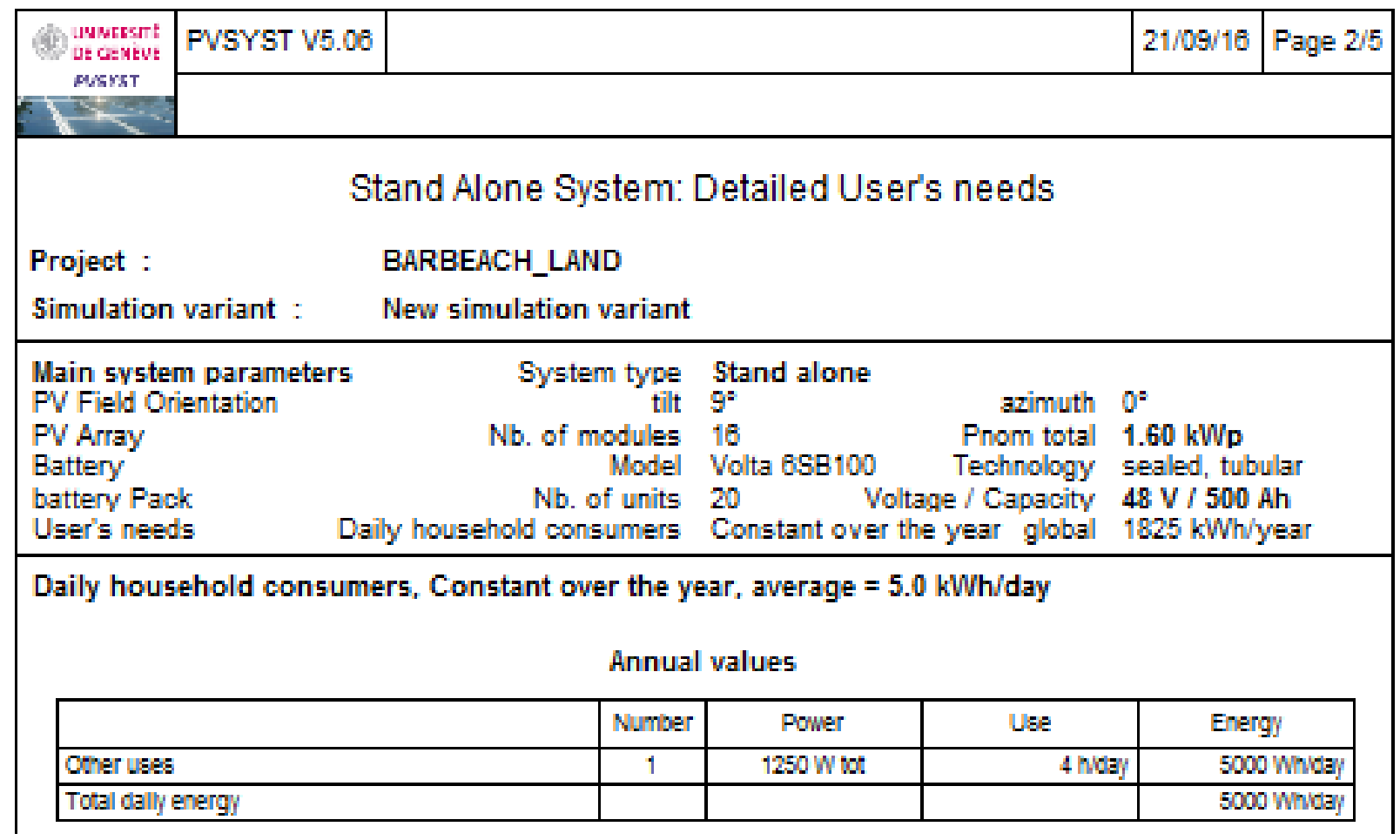

Figure 2. The User's Daily Load Demand. 


\begin{tabular}{|c|c|c|c|c|c|c|c|c|}
\hline 4 & & \multicolumn{5}{|c|}{ Simulation variant: New simulation variant } & - & $\square$ \\
\hline Close Print & Export Help & & & & & & & \\
\hline \multicolumn{9}{|c|}{$\begin{array}{l}\text { New simulation variant } \\
\text { Balances and main results }\end{array}$} \\
\hline & $\begin{array}{l}\text { GlobHor } \\
\text { kWh/m² }\end{array}$ & $\begin{array}{l}\text { GlobEff } \\
\mathrm{kWh} / \mathrm{m}^{2}\end{array}$ & $\begin{array}{c}\text { E Avail } \\
\text { kWh }\end{array}$ & $\begin{array}{c}\text { EUnused } \\
\text { kwh }\end{array}$ & $\begin{array}{l}\text { E Miss } \\
\text { kWh }\end{array}$ & $\begin{array}{l}\text { E User } \\
\text { kWh }\end{array}$ & $\begin{array}{l}\text { E Load } \\
\text { kWh }\end{array}$ & SolFrac \\
\hline January & 163.7 & 169.0 & 231.0 & 57.58 & 0.12 & 154.9 & 155.0 & 0.999 \\
\hline February & 153.7 & 155.2 & 215.2 & 66.38 & 0.10 & 139.9 & 140.0 & 0.999 \\
\hline March & 169.2 & 165.5 & 227.0 & 64.07 & 0.15 & 154.9 & 155.0 & 0.999 \\
\hline April & 156.3 & 148.3 & 196.7 & 36.56 & 0.11 & 149.9 & 150.0 & 0.999 \\
\hline May & 147.6 & 136.6 & 170.5 & 10.73 & 0.06 & 154.9 & 155.0 & 1.000 \\
\hline June & 121.2 & 111.7 & 130.5 & 0.08 & 20.33 & 129.7 & 150.0 & 0.864 \\
\hline July & 122.4 & 113.0 & 137.8 & 5.00 & 19.63 & 135.4 & 155.0 & 0.873 \\
\hline August & 123.4 & 116.4 & 138.1 & 0.15 & 32.99 & 122.0 & 155.0 & 0.787 \\
\hline September & 122.7 & 117.6 & 144.2 & 7.05 & 0.04 & 150.0 & 150.0 & 1.000 \\
\hline October & 141.0 & 139.3 & 167.6 & 3.49 & 0.02 & 155.0 & 155.0 & 1.000 \\
\hline November & 148.5 & 151.3 & 189.6 & 16.40 & 0.06 & 149.9 & 150.0 & 1.000 \\
\hline December & 160.3 & 167.0 & 225.7 & 61.86 & 0.12 & 154.9 & 155.0 & 0.999 \\
\hline Year & 1730.1 & 1690.8 & 2173.9 & 329.35 & 73.73 & 1751.3 & 1825.0 & 0.960 \\
\hline
\end{tabular}

Figure 3. The SAPV Systems Solar Fraction.

Table 3. The Monthly Energy Yield and Unit Cost Of Energy, where Annual Average Energy Yield, Eannual $=1751.4 \mathrm{kWh}$ and Annual Unit Cost Of Energy, $U_{\text {annual }}=141$ Naira/ $\mathrm{kWh}$

\begin{tabular}{llllll}
\hline & $\begin{array}{l}\text { Energy Delivered To } \\
\text { The Load }\end{array}$ & Energy Demand & SolFrac & $\begin{array}{l}\text { Annual Energy Yield Based On The } \\
\text { Output Of Month i, } \boldsymbol{E}_{\boldsymbol{m}(\boldsymbol{i})}\end{array}$ & $\begin{array}{l}\text { Monthly Unit Cost } \\
\text { Of Energy, } \mathbf{U}_{\mathbf{i}}\end{array}$ \\
\hline kWh & $\mathrm{kWh}$ & & $\mathrm{kWh}$ & $\mathrm{Naira} / \mathrm{kWh}$ \\
January & 154.9 & 155 & 0.999 & 1858.8 & 132.8 \\
February & 139.9 & 140 & 0.999 & 1678.8 & 147 \\
March & 154.9 & 155 & 0.999 & 1858.8 & 132.8 \\
April & 149.9 & 150 & 0.999 & 1798.8 & 137.2 \\
May & 154.9 & 155 & 1 & 1858.8 & 132.8 \\
June & 129.7 & 150 & 0.864 & 1556.4 & 158.6 \\
July & 135.4 & 155 & 0.873 & 1624.8 & 151.9 \\
August & 122 & 155 & 0.787 & 1464 & 168.6 \\
September & 150 & 150 & 1 & 1800 & 137.1 \\
October & 155 & 155 & 1 & 1860 & 132.7 \\
November & 149.9 & 150 & 1 & 1798.8 & 137.2 \\
December & 154.9 & 155 & 0.999 & 1858.8 & 132.8 \\
Year & 1751.3 & 1825 & 0.96 & 1751.4 & 141.0 \\
\hline
\end{tabular}




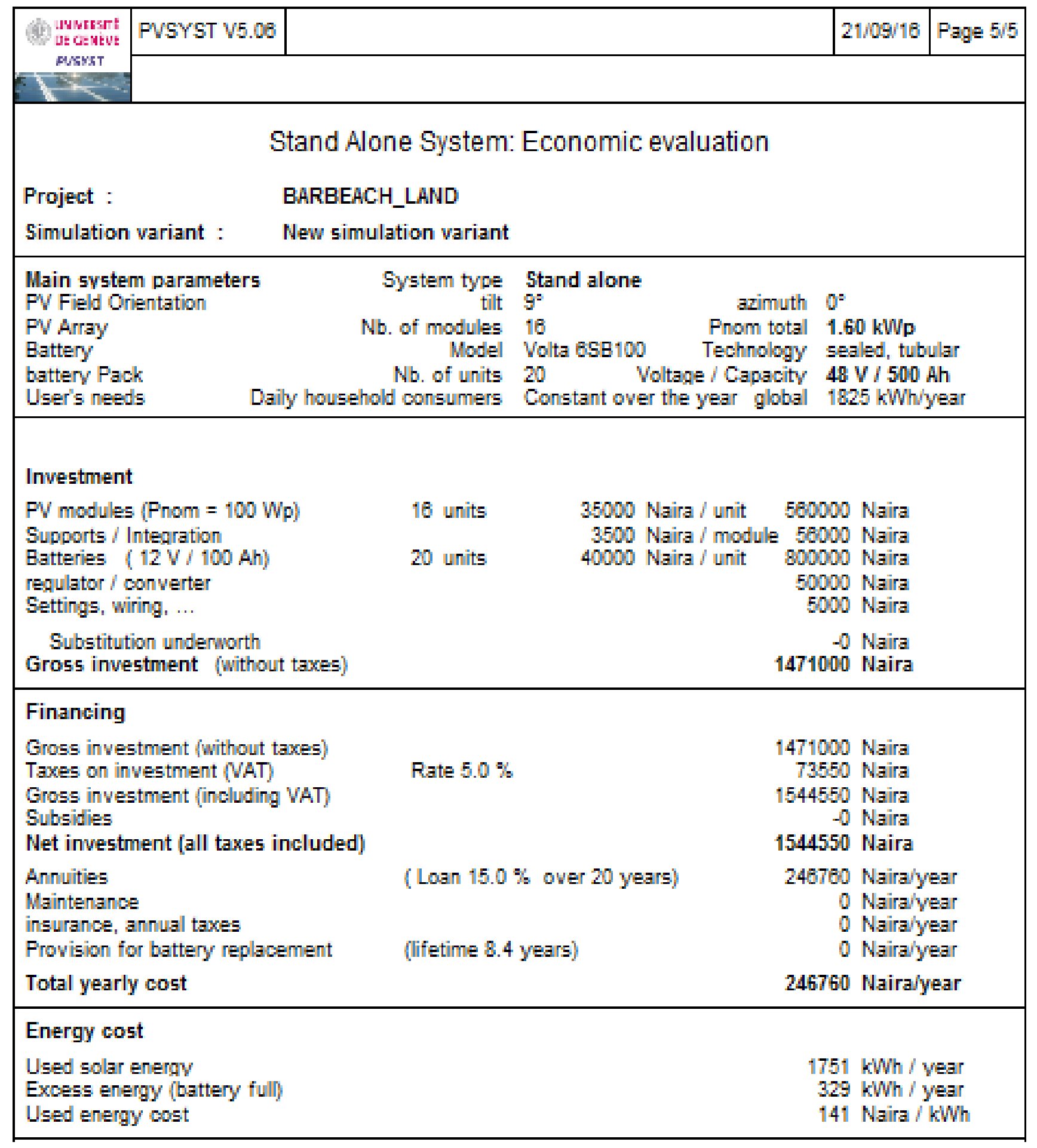

Figure 4. The Economic Analysis Result.

\section{Conclusion}

In this paper, simulation approach is used for the determination of the monthly unit cost of energy generated from standalone PV (SAPV) power system in Imo State. The meteorological data used in the study are compiled from National Aeronautics and Space Administration (NASA) worldwide meteorological database. The meteorological data include 22-year monthly and annual averaged insolation incident on a horizontal surface $(\mathrm{kwh} / \mathrm{m} 2 /$ day) and 22-year monthly averaged air temperature. A hypothetical (assumed) electric load demand data of $5000 \mathrm{kWh}$ per day is used for the simulation. The PVsyst industrial PV system planning software solution was selected to model and simulate the entire PV system. PVSyst uses life cycle cost analysis approach to determine the investment cost and unit cost of energy generated from the PV system. The average total 
energy supplied to the user (load) along with unit cost of energy in a year and in each month are determined.

\section{References}

[1] Timmons, D., Harris, J. M., \& Roach, B. (2014). The Economics of Renewable Energy. Global Development And Environment Institute, Tufts University, Medford, MA, 52.

[2] Lior, N. (2008). Energy resources and use: The present situation and possible paths to the future. Energy, 33 (6), 842-857.

[3] Shafiee, S., \& Topal, E. (2009). When will fossil fuel reserves be diminished? Energy policy, 37 (1), 181-189.

[4] Widén, J., Carpman, N., Castellucci, V., Lingfors, D., Olauson, J., Remouit, F., ... \& Waters, R. (2015). Variability assessment and forecasting of renewables: A review for solar, wind, wave and tidal resources. Renewable and Sustainable Energy Reviews, 44, 356-375.

[5] Smith, Z. A., \& Taylor, K. D. (2008). Renewable and alternative energy resources: a reference handbook. ABC-CLIO.

[6] Ezugwu, C. N. (2015). Renewable Energy Resources in Nigeria: Sources, Problems and Prospects. Journal of Clean Energy Technologies, 3 (1).

[7] Pandey, A., \& Singh, D. K. Modelling of Photovoltaic Solar Panel for Maximum Power Point Tracking. International Journal of Science and Research (IJSR) Value (2013): 6.14

[8] Omer, A. M. (2008). Energy, environment and sustainable development. Renewable and sustainable energy reviews, 12 (9), 2265-2300.

[9] Boluk, G. (2013). Renewable Energy: Policy Issues and Economic Implications in Turkey. International Journal of Energy Economics and Policy, 3 (2), 153.

[10] Tsoutsos, T., Frantzeskaki, N., \& Gekas, V. (2005). Environmental impacts from the solar energy technologies. Energy Policy, 33 (3), 289-296.

[11] Prakash, R., \& Bhat, I. K. (2009). Energy, economics and environmental impacts of renewable energy systems. Renewable and sustainable energy reviews, 13 (9), 2716-2721.

[12] Kjaer, S. B., Pedersen, J. K., \& Blaabjerg, F. (2005). A review of single-phase grid-connected inverters for photovoltaic modules. IEEE transactions on industry applications, 41 (5), 1292-1306.
[13] King, D. L., Kratochvil, J. A., \& Boyson, W. E. (2004). Photovoltaic array performance model (pp. 1-43). United States. Department of Energy.

[14] Omar, A. M., \& Shaari, S. (2009). Sizing verification of photovoltaic array and grid-connected inverter ratio for the Malaysian building integrated photovoltaic project. International Journal of Low-Carbon Technologies, ctp033.

[15] Yerli, B., Kaymak, M. K., İzgi, E., Öztopal, A., \& Şahin, A. D. (2010). Effect of derating factors on photovoltaics under climatic conditions of Istanbul. World Academy of Science, Engineering and Technology, 44, 1400-1404.

[16] Marion, B., Adelstein, J., Boyle, K., Hayden, H., Hammond, B., Fletcher, T.,... \& Rich, G. (2005, January). Performance parameters for grid-connected PV systems. In Conference Record of the Thirty-first IEEE Photovoltaic Specialists Conference, 2005. (pp. 1601-1606). IEEE.

[17] Fuller, S. (2010). Life-cycle cost analysis (LCCA). National Institute of Building Sciences, An Authoritative Source of Innovative Solutions for the Built Environment, 1090.

[18] Kale, N. N., Joshi, D., \& Menon, R. (2016). Life cycle cost analysis of commercial buildings with energy efficient approach. Perspectives in Science.

[19] Ghadge, C. (2012). Analysis of Life Cycle Costs and Social Acceptance of Solar Photovoltaic Systems Implementation in Washington State Public Schools (Doctoral dissertation, University of Washington).

[20] Arif, M. O. H. D., \& Khan, M. E. (2010). Design and life cycle cost analysis of a SAPV system to electrify a rural area household in India. Current World Environment, 5 (1), 101-106.

[21] Nafeh, E. S. A. (2009). Design and economic analysis of a stand-alone PV system to electrify a remote area household in Egypt. The open renewable energy journal, 2 (1).

[22] Abdulateef, J., Sopian, K., Kader, W., Bais, B., Sirwan, R., Bakhtyar, B., \& Saadatian, O. (2012). Economic analysis of a stand-alone PV system to electrify a residential home in Malaysia. In Advances in fluid mechanics and heat \& mass transfer conference (pp. 169-74).

[23] Hassan, Q., Jaszczur, M., Mohamed, M., Styszko, K., Szramowiat, K., \& Gołaś, J. (2016). Off-grid photovoltaic systems as a solution for the ambient pollution avoidance and Iraq's rural areas electrification. In E3S Web of Conferences (Vol. 10, p. 00093). EDP Sciences. 